\title{
8
}

\section{Forest Governance in Latin America: Strategies for Implementing REDD}

\author{
Mariel Aguilar-Støen, Fabiano Toni and Cecilie Hirsch
}

\section{Introduction}

Global interest in and attention to forests have grown as concerns about global warming and climate change have taken a heightened position in international policy debates. Forests have been repositioned in international arenas as repositories of global value for their contribution to carbon sequestration and climate mitigation (Fairhead and Leach, 2003; Peet, Robbins and Watts, 2011). In this context, Latin American forests are seen as globally important in fighting climate change.

Carbon emissions in developing countries, particularly in Latin America, are related mostly to land-use and land-cover change. In Latin America, energy accounts for only $28 \%$ of regional emissions, whereas land use, land-use change and forestry (LULUCF) accounts for $67 \%$ (Barcena et al., 2010). Forests cover about 11.1 million $\mathrm{km}^{2}$ and savannahs 3.3 million $\mathrm{km}^{2}$, comprising several different types of vegetation. The region as a whole has the world's greatest forest loss (Pacheco et al., 2010). Most of the forest conversion in Latin America occurs in the Amazon basin. Some countries are already being pressed to reduce emissions related to land-cover change, particularly deforestation. Political pressure comes from the international arena in many forms and is exerted by several actors: sovereign states, international organizations, media, civil society networks and others.

Several Latin American governments have turned to climate policies as an opportunity to improve environmental governance. Current discussions focus on a set of policies known as REDD in developing countries plus carbon-sequestering forest activities. REDD was originally 
designed as a payment for environmental services - that is, a voluntary transaction where a well-defined service (or a land-use system likely to secure that service) is being "bought by a buyer from a provider, if and only if the provider secures the service provision" (Wunder, 2005). REDD is based on the idea that it is possible to reduce deforestation by offering economic compensation to forest users for not changing the use of forestlands. It is seen as a win-win approach that would potentially address the trade-offs between forest conservation and economic development. Some analysts claim that REDD projects have the potential to generate enough money to end deforestation in tropical countries (Nepstad et al., 2009).

Although originally presented as an "apolitical" technological fix (cf. Li, 2007), REDD has encountered much criticism, and early proposals faced fierce political resistance. The neoliberal idea of the commodification of nature seemed repellent to individuals and even to countries, which fear that developed countries would use their economic power to increase or leave unaddressed their carbon emissions at the expense of developing countries. There were also fears that REDD would benefit actors who have historically been responsible for deforestation, such as ranchers and large-scale farmers, while excluding the less privileged forest-dwellers, who cannot bear the transaction costs of carbon markets and do not even have the title to their lands (Boyd, Gutierrez and Chang, 2007; Blom, Sunderland and Murdiyarso, 2010).

REDD proved to be much more complex than a simple carbon-market arrangement. Since it is a project "in the making", it necessarily leaves room for bargaining and negotiations as to how forest and climate policies will take shape in specific contexts. As a result, REDD quickly moved from strictly carbon storage to having multiple objectives, including biodiversity conservation and the enhancement of local livelihoods (Angelsen and McNeill, 2012). This even more complex mechanism is not yet settled. There are important struggles at international, national and local levels to define how REDD should be implemented.

REDD can be seen as a multilevel project of environmental governance. By environmental governance we mean "a set of mechanisms, formal and informal institutions and practices by way of which social order is produced through controlling that which is related to the environment and natural resources" (Bull and Aguilar-Støen, 2015: 5). Some decisions regarding REDD are taken at the global level, other decisions are taken at the national level and finally actions, projects and initiatives are implemented at the local level. This complexity might result in the hybridization of REDD, and, as the idea is appropriated by different 
actors, such hybridization might also result in subtle or open power struggles among actors at the different levels.

REDD emerged as a global initiative from the climate negotiations, but it is going to be implemented in countries with very different approaches to combating deforestation, technical capacity, institutional and political settings, levels of decentralization of forest governance, budgets and so forth. Therefore it is possible to expect REDD to unfold in quite different ways across the region. To understand and analyse the diversity in which REDD is evolving in Latin America, in this chapter our analytical focus will move across different scales and will make use of some paradigmatic examples, with special emphasis on the countries representing such cases. Our analysis will show that despite their initial opposition, some groups of actors support REDD and are taking advantage of the new opportunities that the scheme offers. REDD initiatives, for example, have become an economic opportunity for both state and national governments as well as for international and regional environmental NGOs.

This chapter is organized as follows. After this introduction, we present our main analytical argument. The following section examines the phased approach to implement REDD in Latin America. In the third section, we present what we have identified as three general strategies to implement and shape REDD across the region. In the next section, we discuss some examples of how pilot projects are taking off in the region. Finally, we present our conclusions.

\section{Hybrid environmental governance and REDD}

Forests in Latin America are territories where several conflictive interests meet. However, there is no consensus on the conceptualization of the causes and consequences of deforestation. Diverse conceptualizations of deforestation are closely related to claims over forest management and over resources (Fairhead and Leach, 2003). Forests are socially, culturally, ecologically, economically and symbolically valuable to different actors, including indigenous peoples, local users, governments, corporations, illegal cartels, NGOs, nations and the globe, albeit in different ways and for different reasons (Fairhead and Leach, 2003). All these actors have different potentials to exert power and access arenas to influence REDDrelated policy-making.

The very notion of "environmental governance" implies that there is some sort of hybridity in terms of the actors, and in the mechanisms and practices it involves. This means that both public and private 
actors participate on various scales, in producing models and frames for governance. By focusing on REDD we pay attention to emergent governance arrangements that include state actors, subnational governments, multilateral institutions, scientists, NGOs and business (Karkkainen, 2004).

The conceptualization of REDD, its formulation, negotiation and implementation involve a range of actors because the necessary resources for such tasks are not controlled by a single entity. As our analysis will suggest, these resources function as sources of legitimacy for the participation of different actors in REDD. By legitimacy, we mean who is making "the rules of the game" in REDD preparations and negotiations. We see legitimacy as a source of power to create and support certain policies and practices, while simultaneously hindering others. Legitimacy rests, among other things, on the shared acceptance of rules by different groups of actors with shared interests on the issue to be governed (Bernstein, 2004).

REDD, however, is still a project "in the making". Because of that, this chapter only aims to examine two processes: (1) how different countries engage with REDD; and (2) how different actors within these countries get involved in a range of activities seen as necessary for the future implementation of REDD on the ground. In other words, our analysis will not focus on the outcomes of the REDD initiative because such outcomes are still uncertain.

Our proposition in this chapter is that REDD as a concept has been "black-boxed" (Latour, 1987; Forsyth, 2003; Goldman, Nadasdy and Turner, 2011). By that we mean that those engaged in REDD do not consider it necessary to further discuss or question what REDD means. This does not imply, however, that there are no other actors - who perhaps are not directly involved in REDD negotiations - who actually question and challenge the initiative. REDD policy-making reflects how different interests are negotiated between different actors on various geographical scales. In this chapter we will argue that a "distortion" of REDD - from a simple market mechanism to a complex multistakeholder, contested political processes - is one of the ways that the idea gets wide support from a range of actors and makes the hybridization we refer to above possible. REDD as a concept is broad and vague enough to permit different interpretations that would fit the goals of different actors (Angelsen and McNeill, 2012). This has allowed countries in Latin America to pursue different paths regarding the emphasis given to how to finance REDD (fund based or carbon markets) and what issues should be addressed before REDD actions are implemented. 
To support our proposition we discuss three different strategies used by Latin American countries to engage or resist the REDD initiative. Also, the "distortion" works at more local levels by allowing different actors to get involved in planning activities. We will also discuss planning activities in the Amazon region to support our proposition and will show how there are some key resources that galvanize the participation of certain actors in REDD preparations. By key resources, we mean resources that can be "traded" to gain legitimacy to participate in REDD processes at local levels. As we will show below, access to networks and knowledge production are among such key resources.

\section{REDD in Latin America and the phased approach}

In 2010, during the conference of the parties of the United Nations Framework Convention on Climate Change (UNFCC), governments agreed to adopt a phased approach for REDD. The idea of a phased approach came from a report (Angelsen et al. 2009) prepared by the Meridian Institute for the Government of Norway. The idea put forward by the report by Angelsen et al. (2009) was adopted by the UNFCC Cancun agreement ${ }^{1}$ (Agrawal, Nepstad and Chhatre, 2011). The Cancun agreement stipulates that countries participating in REDD should implement activities by phases. These phases are (1) development of national REDD strategy plans and capacity-building; (2) implementation of national plan and demonstration activities; and (3) results-based actions with full measuring, reporting and verification. So far, most Latin American countries involved in REDD are in Phase 1. Guyana is in Phase 1 but has already received funding from Norway that would correspond to phases 2 and 3; Brazil is in Phase 2, entering Phase 3 (Figure 8.1).

There are many mechanisms for financing Phase 1, including public funds from the countries implementing REDD or from donors: the Forest Investment Programme supported by the Climate Investment (Multilateral Investment Banks), the UN-REDD programme, and the Forest Carbon Partnership Facility (FCPF) of the World Bank. The latter two are the main sources of funding, and some countries such as Bolivia, ${ }^{2}$ Peru and Ecuador have applied to both. On the other hand, Brazil established its own Amazon Fund in 2008, through which reduced deforestation is going to be financed in the country. Guyana established the Guyana REDD investment fund (GRIF) in 2010 as part of a cooperation agreement with Norway in the framework of the Low Carbon Development Strategy (LCDS) of Guyana. ${ }^{3}$ The LCDS of Guyana was prepared by the consultancy firm McKinsey, 

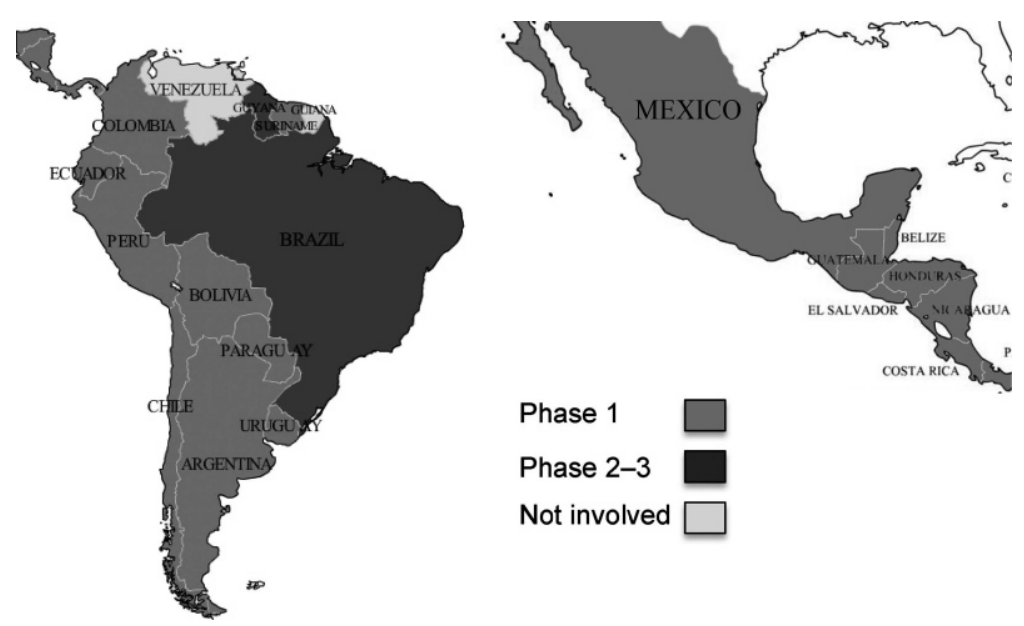

Phase 1

Phase 2-3

Not involved

Figure 8.1 Latin American countries in relation to their participation in REDD and the phased approach

and Guyana's president embarked upon an international campaign to attract funding for the initiative. Venezuela and French Guyana do not participate in any REDD initiatives under the United Nations or the World Bank.

In 2013, Norway was the single major financial contributor to the UN-REDD Programme, FCPF, the Brazilian Amazon Fund and the GRIF. Norway contributes $82 \%$ of the total budget of the UN-REDD Programme, $44 \%$ of the total budget of FCPF, $87 \%$ of the total budget of the Amazon Fund, and $100 \%$ of the GRIF. ${ }^{4}$ The country is one of the major players in defining REDD at the global level and has some influence on the way in which REDD is advancing at national levels.

The incorporation of the phased approach launched by the Meridian report in the UNFCC's Cancun agreement contributes to stressing a particular way of prioritizing the activities necessary for the implementation of REDD. This particular approach is being reproduced in national contexts because its proponents believe in the technical superiority of the approach and because it promotes comparability and compatibility between countries, but not necessarily a solution to the problem of deforestation (Fairhead and Leach, 2003). As it might seem obvious to most, the driving forces behind deforestation vary enormously, as do the political and economic settings in each country, the interests and alliances among different actors, and the roles played by the state and non-state actors. The challenges associated with deforestation 
in the region are as political as technical, but the phased approach de-emphasizes other dimensions of the problem.

In the phased approach, institutional arrangements and technical capacity to measure deforestation are emphasized. REDD will rely on the specific target of measuring reduced emissions from deforestation. In Latin America, in addition to Brazil, only Mexico and Costa Rica have comparable technical capacity in place to measure forest-cover change. Consequently, a strong emphasis in readiness preparations in all other countries in Latin America is currently placed on strengthening technical infrastructure to monitor forest change. ${ }^{5}$ A strong emphasis on measuring and monitoring forest cover has a depoliticizing effect on the understanding of deforestation's causes, consequences and risks to impose control mechanisms that might harm local livelihoods (Scott, 1998). If the causes and consequences of deforestation are not properly understood in each country, it might be that those who live closer to forested areas bear the blame for deforestation and the responsibility for avoiding it.

\section{The three REDD strategies in Latin America}

Several Latin American countries (Brazil, Argentina, Paraguay, Peru and Venezuela) have been sceptical about offsets from carbon emissions trading, as declared by the countries at the BASIC Ministerial Meeting on Climate Change in Foz do Iguaçu, Brazil, in September 2013. ${ }^{6}$ The ministers called for environmental integrity and stressed that "results-based payments shall not be used to offset mitigation commitments by Annex I countries [industrialized countries]". The ALBA ${ }^{7}$ countries have held the same position.

Although the ideas that led to the intellectual elaboration of REDD in part emerged in Brazil (Santilli et al., 2005), the country opposed any attempts to include forests and deforestation under the scope of the Kyoto Clean Development Mechanisms. Without Brazil, any such mechanism would be doomed to fail, considering the magnitude of the country's tropical forests and its rate of deforestation. It is argued that, because of the long history of early initiatives to conserve forests in the region, Latin American countries are in the lead of early efforts to implement REDD (Hall, 2011).

Governments in Latin America have taken different approaches to implement and shape REDD efforts. We have identified three strategies. The first, which we will refer to as the "assertive strategy", is characterized by efforts made by the central government to frame REDD within 
an existing or emerging forest-climate policy framework. Brazil, Mexico and Guyana, for example, are employing this strategy. Countries following guidelines or directions decided at the global level and efforts to accommodate such guidelines in the national context characterize the second strategy, which we will call the "accommodating strategy". Costa Rica, Guatemala, Argentina, Chile, Honduras, Panama, Paraguay, Uruguay, Peru, Colombia, Ecuador and Suriname are pursuing this strategy. Open opposition to certain aspects of REDD or a lack of initiative to implement REDD characterize the third and last strategy, which we will call the "resisting strategy". The countries following this path are Nicaragua, Bolivia, Venezuela and French Guyana. In the paragraphs below we will use one or two countries to illustrate each of the strategies. First we present the assertive strategy because this represents one pole in the continuum between taking the lead and resisting a project. Next we present the accommodating strategy, which represents the situation of most Latin American countries and thus represents the middle ground of the continuum. We finish with the resisting strategy at the other end of the continuum.

\section{The assertive strategy: Brazil}

While most other countries in Latin America were still working to put human capacity in place to deal with REDD within their ministries of the environment, Brazil launched the Amazon Fund in 2008. This, however, represents the way in which the position of Brazil evolved from resistance to leadership.

For many years the Brazilian Government was a fierce opponent of any attempts to include forest- and land-use change in the international negotiations to reduce carbon emissions. This position was justified on the grounds that developed and developing countries share common but differentiated responsibilities concerning global warming. Many opponents of such proposals were afraid that carbon credits would allow rich countries to keep pouring carbon into the atmosphere at the expense of developing countries. Furthermore, Brazil was concerned with any potential threats to its sovereignty and control of its forests resources, particularly in the Amazon. Any clause addressing deforestation could be interpreted as an obstacle to developing the region as the state saw fit.

Even though President Lula himself supported this realist view, as he made clear in 2007 during the opening of the UN General Assembly (Hall, 2008), change in the Brazilian position came from within the government. When President Lula took office in 2003, he appointed Marina Silva, a former senator and rubber tapper leader, as minister of 
the environment. She promoted some institutional changes that ultimately led to a turnaround in the Brazilian official position. The first change came by opening up new opportunities for participation of civil society organizations in policy-making. Knowledge networks formed by activists and scientists developed stronger ties with government officials and became more influential. A related second change was an administrative reform in the Ministry of the Environment. In 2007, Silva created the Secretariat of Climate Change and Environmental Quality, whose top officials were committed to the creation of carbon compensation mechanisms.

Activists and scientists had been discussing proposals to create compensation mechanisms to pay for avoided deforestation since the early 2000s (Santilli et al., 2005). By the time their peers ascended to the new secretariat, the government's efforts to control deforestation were already paying off. Therefore the idea of being compensated by reducing deforestation made much more sense to government officials.

Another crucial component of the policy network supporting compensation was Amazonian state governments. As proposals evolved towards compensating carbon stocks, governors saw an opportunity to channel resources into their states, particularly where there are vast areas under protection. Protected Areas (PAs) have traditionally been considered a burden for state and municipal governments. The benefits of conservation are global, but the perceived costs are local, particularly due to land-use restrictions. The economic losses imposed on states could therefore be, at least partially, offset by this new source of revenue. In 2009, a few months before the UNFCCC COP 15, the governors of all nine Amazonia states met and wrote a letter to the president, pointing out that Brazil was lagging behind other developing countries in the carbon market. They argued that if Brazil was to receive more funds from carbon credits and to reduce its own carbon emissions, REDD mechanisms had to be included in the international carbon market under the UNFCCC (Toni, 2011).

The Amazon Fund was launched as a means to obtain funding from donors to finance the Plan of Action for Protection and Control of Deforestation in the Legal Amazon. The Amazon Fund was created within the Brazilian National Bank of Social and Economic Development (BNDES). The mobilization of civil society, particularly international $\mathrm{NGOs}^{8}$ and other environmentalists since the 1990s, and the engagement of politicians at the state and federal levels have been important for the advancement of REDD-like ideas based on assumptions of the efficiency of economic payments for environmental services to curb deforestation (Hall, 2011). These ideas are also supported by several governors in the 
Brazilian Amazon and coincide with those of the president and the minister of the environment, contributing to create conditions necessary for the Brazilian involvement in REDD. For the Amazon Fund, the government of Brazil pledged to allocate US $\$ 500$ million, but it is estimated that an additional investment of US $\$ 1$ billion per year would be required to fully implement the plan (Meyer, 2010).

Brazil has the technical capacity to monitor changes in forest cover through remote-sensing technology and to ensure transparency to deal with the fund through institutional structures and mechanisms. By 2008, Brazil had already put in place some of the conditions to be enabled by Phase 1 . This in part explains Norway's support of the Amazon Fund, which placed Brazil in phases 2 and 3. The Norwegian support of the Fund is contingent on demonstrating avoided deforestation against a historical baseline (results-based payments). Norway's involvement is also based on ideas of economic rationality, altruism and self-interest ${ }^{9}$ as a humanitarian/environmental protection actor.

The establishment of the Brazilian Amazon Fund can be explained by the combined effect of the activities and initiatives of NGOs, state governors in the Amazon region, and politicians in key positions (the president and the minister of the environment). Norwegian support through Norway's International Forest and Climate Initiative (NIFCI) gave the scheme the final thrust to get the fund started. The Amazon Fund is important for advancing the Brazilian approach to REDD. This approach is well established in existing Brazilian institutions and is in accord with the country's views and priorities.

Brazil's REDD strategy has been characterized by a strong involvement of the central government, but NGOs and lower levels of the public administration have also played a role. The advanced technical capacity of Brazil in terms of remote-sensing and the establishment of a historical baseline of forest cover place the country in a privileged position in regard to the phased approach promoted at the international level. The alliance of Brazil and Norway for financing the Amazon Fund has given Brazil's strategy a very advantageous starting point.

Brazil's approach to financing REDD efforts has been based on the idea of a centralized fund that would allow the country to avoid the voluntary carbon market for financing reduced deforestation. However, the growing involvements of other networks, particularly those in which governors of the Amazon states are involved, have pushed the country towards additional mechanisms for financing avoided deforestation, particularly through their partnership with the governors of California and Illinois. ${ }^{10}$ 
In the following subsection we present the accommodating strategy, which is used by most countries in the Latin American region as mentioned above. To illustrate we use the cases of Colombia and Costa Rica.

\section{The accommodating strategy: Colombia and Costa Rica}

REDD preparation activities in Costa Rica and Colombia have advanced quite differently from those in Brazil. Colombia has the most decentralized public administration in Latin America. Over $40 \%$ of total government spending is allocated by subnational governments against an average of $15 \%$ in the rest of Latin America (Alesina, Carrasquilla and Echavarria, 2005). The administration of forest and other natural resources is also decentralized (Alvarez, 2003). Costa Rica, on the other hand, represents a case of highly centralized forest governance. We will first describe Colombia and subsequently Costa Rica.

The lead for the REDD process in Colombia has been taken by the private sector, particularly business-friendly international NGOs (BINGOs), and not by the central government. Colombia has one of the most decentralized environmental administrations in Latin America. Local environmental authorities (Regional Autonomous Corporations (CARs)) are in charge of the management and administration of all natural resources and environmental issues in the area of their jurisdiction. Although CARs receive a portion of their budget from the central government, they also generate income through tax revenues that come from projects implemented in their jurisdiction. In this way CARs hold significant power to decide the direction of both environmental conservation and development projects.

The Colombian Government highlights the involvement of the private sector in the financing of environmental conservation efforts in various white papers (e.g. the National Strategic Plan for Green Markets produced by the Ministry of the Environment and the National Development Plan 2005-2010). A general perception from the Colombian Government is that private investments with little state regulation in remote forest regions are more economically efficient because they lower their intervention costs and could also offer better-adapted development options. A quote from an official of the Ministry of the Environment illustrates the position:

The market in a way takes care of redistributing the resources at local levels. It is a lot simpler ... it lower our costs ... so, if the state does not receive the $[R E D D]$ money it does not need to invest in the regions 
where they are receiving the money ... well that is good... the government does not need to invest in those regions; in a way they take care of themselves.

All BINGOs operating in Colombia and some local NGOs expressed the same view during our interviews; they too want to increasingly involve private funds in current forestry and development mechanisms.

Within this context, REDD preparations have been largely led by NGOs. The BINGOs working in the country (WWF, Conservation International (CI), The Nature Conservancy (TNC)), ${ }^{11}$ in collaboration with the United States Agency for International Development (USAID) and one local NGO/consulting firm (Corporación Ecoversa), created the Colombia REDD Table in 2008 (Mesa REDD-Colombia). Other private organizations (the Fund for Environmental Action and Children (FAAN), the Natural Patrimony Fund and the Nature Foundation) as well as the Ministry of the Environment and the Institute for Environmental and Meteorological Studies (IDEAM) joined the Colombia REDD table a year after its creation. Participation in the REDD table was not open to all those who were interested. Instead, the control of certain resources (i.e. knowledge, networks and technologies) legitimate and facilitate their participation. Civil society organizations, universities and others who are not considered "REDD experts" by the terms established by the REDD table are excluded.

The REDD table in Colombia has positioned itself as a legitimate network to be consulted or to provide inputs on various REDD-related issues. For instance, the funds provided by the FCPF for REDD preparation activities are administrated on behalf of the government by an NGO (FAAN). The REDD table is the most active and important network that disseminates information concerning REDD in Colombia and that reports to the World Bank. ${ }^{12}$

The Colombia REDD table strongly supports the inclusion of carbon markets in the mechanisms to finance REDD. This has also been the position of Colombia in the international climate negotiations, in which it has insisted on countries' freedom to choose between different financial sources, markets and/or an international fund. The voluntary carbon market is a salient project among members of the Colombia REDD table, partially due to the engagement of international and some local NGOs with actors interested in, connected to or involved with the carbon business. These actors include the local public environmental authorities (CARs), national and international business partners (i.e. mining and energy-producing companies, plantation companies, forest 
companies, carbon-marketing companies), international research organizations, development cooperation agencies, and indigenous and AfroColombian leaders. These engagements would allow the channelling of funds from a range of private businesses directly into carbon-market projects that could eventually become part of REDD.

The REDD programme in Costa Rica is seen as a means to strengthen and broaden the Payment for Environmental Services (PES) programme. PES emerged in Costa Rica in the 1990s as a response to the perceived problem of deforestation and forest loss. Between 1986 and 1991, the country lost $4.2 \%$ of forest cover per year (Sanchez-Azofeifa, Harriss and Skole, 2001), suggesting that Costa Rica had one of the highest deforestation rates in the world. The launching of REDD occurred ten years after Costa Rica became the first country in the world to establish a system of PES in 1997. The financial structure of the Costa Rican PES programme is a hybrid of market-like mechanisms, subsidies and state regulations. This is evident in the way that the programme is funded: while it receives $3.5 \%$ of the revenues from a tax on fossil fuels, it also depends on loans from the World Bank, from a series of grants from the Global Environmental Facility (GEF), from NGOs, from contracts with national companies (Pagiola, 2008) and from international governments. The German Government, through the German Reconstruction Credit Institution (Kreditanstalt für Wiederaufbau (KfW)), provided US\$12 million for a five-year contract in 2007, and in 1996, Norway bought 200,000 tonnes of carbon-emission reduction credits for US\$10 per tonne (Russo and Candela, 2006). The REDD national strategy is being discussed within the framework of the national PES programme. Because the current PES programme is unable to cover the demand for payments for environmental services, which is very high, REDD is seen as an avenue to increase the coverage of the national PES.

Costa Rica applied to the FCPF in 2008 to fund the REDD readiness preparations. ${ }^{13}$ A grant was approved in 2010. In Costa Rica, public institutions are leading the REDD readiness preparations. The PES experience and Fondo Nacional de Finaniciamiento Forestal (FONAFIFO) largely shape the REDD process. FONAFIFO's board of directors is the REDD coordinating entity in Costa Rica. The board will include one representative from indigenous people's organizations and one representative from civil society.

FONAFIFO carried out a series of dissemination and outreach activities to engage with different stakeholder groups. As for indigenous peoples, it has invited the Indigenous Integral Development Associations (Asociación de Desarrollo Integral Indígenas (ADIIs)) to participate 
in information meetings and activities. Indigenous leaders contest the legitimacy of the ADIIs in representing indigenous peoples. In 1982, in an effort to make the indigenous territories legible to the state (cf. Scott, 1998), the Government of Costa Rica established the ADIIs as the legal representative bodies of indigenous peoples.

To carry out PES in indigenous territories, the government designated the ADIIs as the collective representative institutions of indigenous peoples vis-à-vis FONAFIFO. The ADIIs became responsible for distributing the benefits from PES in indigenous territories and for helping FONAFIFO to implement PES in the indigenous resguardos. Currently, indigenous leaders challenge this decision, arguing that the ADIIs are official government bodies that "represent" and govern each indigenous territory by law, but do not necessarily represent or respect traditional ways of organization and are not accountable to indigenous peoples. FONAFIFO carried out a series of early information dissemination workshops and it has engaged in an initial dialogue about the REDD process with a range of stakeholder groups, and with indigenous peoples in the Atlantic and Pacific areas through the structure of the ADIIs.

Costa Rica recognizes carbon, insofar as it is considered an environmental service, as property of the landowner, by law. The country has chosen a national approach to reduced emissions accounting and the development of a national baseline for avoided deforestation. At the international level, Costa Rica, similar to Colombia, advocates for a mix of funding for REDD. The approach in Costa Rica is towards a centralized REDD programme. In Colombia, on the other hand, the approach is towards a decentralized system. These two different approaches reflect the way in which forest governance is understood in the two countries. In the following subsection we will analyse the third and last strategy, using Bolivia as the example.

\section{The resisting strategy: Bolivia}

Bolivia has resisted REDD as part of carbon markets and offsets, based on the idea of environmental justice and the non-commodification of nature. The current Bolivian position on REDD was first communicated in a letter to the General Assembly of the United Nations in 2008, emphasizing "direct compensation from developed to developing countries, through a sovereign implementation that ensures broad participation of local communities...". In its second communication to the UNFCCC in 2009, Bolivia stated that the country did not support carbon markets "or the possibility of developing new flexibility in this area", and called for domestic action for emissions reduction, 
under the argument that the "carbon market allows developed countries to continue to pollute at home while developing countries face unfair restrictions".

The position was not a complete rejection of REDD but rather an attempt to reshape it and to broaden the international perspective on both forests and carbon. Different actors were involved in the planning of a national joint programme in Bolivia, beginning in 2008, and Bolivia was one of the first pilot countries in the UN-REDD programme from 2009 onwards. A REDD team was set up in the Ministry of the Environment (MAYA) as part of a larger national strategy for curbing deforestation (Estrategia Nacional de Bosque y Cambio Climatico, MAYA, 2009). The setting up of a national REDD programme was supported by German (Deutsche Gesellschaft für Internationale Zusammenarbeit (GIZ)) and Danish cooperation at the time, and a parallel process was started with the FCPF of the World Bank. The UN-REDD programme was presented for civil society actors in 2010, and four indigenous and peasant organizations approved a capacity-building plan.

Beginning in 2010, different currents both inside and outside the government caused confusion about the Bolivian position. At the People's Conference for Climate Change and the Rights of Mother Earth in Cochabamba in April 2010, where many Bolivian officials also participated, a declaration rejecting all forms of REDD/REDD+/REDD++ was presented..$^{14}$ Following the conference, the negotiation team from the Ministry of Foreign Affairs (with representatives from the Unidad de Madre Tierra) brought the Cochabamba position to the climate negotiations in Cancun as promised, while the Ministry of the Environment signed off on the UN-REDD programme on the condition that UN-REDD would respect the Bolivian position against carbon markets. ${ }^{15}$ The collaboration with the World Bank was halted, and Bolivia never handed in a signed version of the formal document Readiness Plan Idea Notes (R-PIN).

The confusion and lack of advancement of the UN-REDD programme in the 2008-2011 period also opened up the arena for private actors and NGOs to get involved in REDD-like activities. Local communities have reported that private actors (represented by NGOs, a Santa Cruz-based company and local businessmen) contacted communities, asking them to sign "REDD contracts" that involved the lease of land for 90-100 years, in exchange for untouched conservation areas and the "selling of oxygen". The government later stopped the attempts.

In 2008 the national NGO Friends of Nature Foundation (FAN), with support from the Gordon and Betty Moore Foundation, set up an 
indigenous REDD project in the Amazon (Beni Department). The government, originally a partner in the project, withdrew in 2010. Several regional and local indigenous organizations also withdrew, making the argument that the NGO would have too much power over the project and the resources involved. Furthermore, the local communities participating in the project rejected the component regarding quantifying emissions reductions, and the project was left only with select components that addressed sustainable forest management, the enforcement of Brazil nut collection and enhanced control of the area against illegal logging. The project was in operation until 2012.

Later in 2011, a conflict between the central government and the lowland indigenous organization Confederación de Pueblos Indígenas de Bolivia (CIDOB) over a road-building project through the national park TIPNIS led to a rupture in contact among the ministries, public agencies and the indigenous organization, hampering the possibilities for further dialogue about the UN-REDD project. The plan for initiating the participatory planning process for the UN-REDD programme was set on hold. Meanwhile, CIDOB called for direct REDD funding to indigenous areas and for the self-management of funds.

A parallel process was started in 2011 to develop a mechanism for the sustainable management of forests, and joint climate-change mitigation and adaptation efforts. The process involved a number of national NGOs, academics and public entities, such as the Authority for Forest and Land (ABT), the National Institute for Agricultural Innovation (Iniaf) and the Forest Directorate in MAYA. Bolivia hoped that the mechanism could be supported through an alternative REDD scheme outside the carbon market. The mechanism was included in the Law of Mother Earth in 2012, with an emphasis on holistic management of the forests. A team was set up to facilitate the exchange of information and meeting arenas. As public entities had poor official records of deforestation in Bolivia, the participation of the NGOs (e.g. FAN) with such expertise was crucial for the team. Former officials, the Noel Kempff Museum of Natural History and representatives from research institutions and social organizations contributed with important experience and information, forming a final project document that was presented to the UN-REDD in 2012.

In 2011, Bolivia informed the policy board of the UN-REDD programme about its desire to modify its original National Programme document. Two contradictory communications, which were sent from Bolivian officials to the policy board in December 2011 and March 2012, led the board to freeze the funds and send a high-level mission to Bolivia 
in June 2012. The mission concluded that there were several challenges concerning the mechanism (e.g. the lack of an incentive system based on verified reductions of emissions, the targeting of drivers, and the lack of full participation from the indigenous organization CIDOB in the making of the mechanism) and that the project was not eligible for full financing by the UN-REDD programme. Later, contrasting declarations about the participation of indigenous organizations in the making of the mechanism were also communicated to the UN-REDD policy board. The mission finally recommended that the National Joint Programme be implemented in its original form, and that it neither be redrafted nor replaced with the new Bolivian mechanism. Bolivia agreed to continue with the programme, and a small part of the UN-REDD financing was channelled to the mechanism (such as the register of all forest initiatives, forest inventory and the mapping of land-use change). ${ }^{16}$

The proposal for an alternative mechanism was marginalized by powerful REDD donor countries in the international negotiations, claiming it would lead to the fragmentation of the REDD project. Finally, in 2013, Denmark, Switzerland and the EU granted support of over US\$43 million to the Bolivian mechanism. At the international level, Bolivia has worked insistently with the inclusion of non-market-based approaches, such as joint mitigation and adaptation - methodological issues related to non-carbon benefits - and it continues with its strong opposition to carbon-market mechanisms.

Due to opposing currents both within and outside the Bolivian Government, different actors in Bolivia have pursued slightly different strategies to influence and shape REDD, from complete rejection to the reshaping of the initiatives, locally, nationally and internationally. However, the rejection of carbon markets has been a common position across the majority of actors involved, as well as the integration of indigenous rights and the recognition of different functions of the forests. The role of indigenous organizations and indigenous autonomy is still to be defined in the Bolivian mechanism, along with clear strategies to work with the drivers of deforestation.

In the following section, we shift our focus to analyse ongoing efforts at local and national levels. We will focus on demonstration and readiness activities, and the actors involved in them.

\section{REDD projects in Latin America}

An important component of the planning phase of REDD is demonstration and readiness activities. These are projects implemented 
at the local level to test the options available for countries and communities. REDD projects can be seen as a means to understand how REDD will unfold on the ground; REDD demonstration activities are seen as means to learn lessons for future REDD implementation. These early implementation projects influence debates about REDD, the ways in which so-called co-benefits are being addressed, and who is involved and who benefits from REDD.

In principle, REDD country strategies to be defined in Phase 1 are the first step in the implementation of REDD national policies. National REDD strategies would define the current situation in each country and the direction in which the country is going to move in terms of reduced carbon emissions from deforestation, addressing so-called co-benefits and defining who would benefit from economic payments. In practice, however, numerous REDD projects are taking place before the design of a country's REDD strategy is finished or in parallel with its development. Early implementation projects are informing the policy-making process in each country and at the global level. Proponents of REDD projects stand in a better position than other actors, who do not have any experience with such projects, to influence REDD debates because not having knowledge about REDD is a barrier for being included in the official debates.

We have identified three approaches employed by actors involved in early REDD planning, implementation and readiness projects, and the consequences of such approaches. The first one is knowledge production and dissemination. Second is the creation of technologies or standards to legitimize or validate projects. The third approach is enrolment in new, emerging or alternative networks. In what follows we analyse these three approaches by highlighting who is involved, the resources mobilized to employ each approach, and the outcome. It is worth saying that these approaches are not mutually exclusive, and different actors within each country put distinct emphasis on each of these approaches.

\section{Creation of knowledge and dissemination of information}

Our findings indicate that, to a great degree, networks involving NGOs and international research institutions with support from development cooperation agencies and private actors are creating and disseminating knowledge about REDD in the region. These networks systematize information about REDD in Latin America and at the global level. They are having a great influence in defining what a REDD project is, who the legitimate implementers are, who will benefit from it and how. The Center for International Forestry Research (CIFOR), the NGO Global 
Canopy Programme, ${ }^{17}$ and the voluntary REDD database ${ }^{18}$ created at the Oslo Climate and Forest Conference in 2010 produce compilations and databases that include all types of REDD-like projects.

The majority of REDD projects are being initiated or planned by private actors in private lands, including national and international private companies, and local and international NGOs (WWF, CI, WCS, TNC, IUCN and Rainforest Alliance). In some cases, pilot projects are executed with the participation of state governments in coalition with BINGOs. Fair-trade cooperatives, carbon certifiers and research institutions are also involved in pilot projects. Pilot project proponents act as de facto researchers, testing REDD implementation modalities, and producing information and knowledge about the projects.

As for funding sources for the projects, development cooperation aid money, particularly from Norway and Germany, as well as private funds, is the most important source. But here it is necessary to explain in more detail what types of private fund are involved. The range is wide and includes (1) direct investments in particular projects from investors from the USA, Europe, China and India; (2) direct investments from companies (e.g. the largest Brazilian mining company, Vale); (3) investments that private companies make in BINGOs; and, similarly, (4) partnerships between local NGOs and private companies as part of their CSR portfolio; (5) a plethora of alliances among domestic NGOs and local-level environmental authorities (CARs), national and international business partners (mining and energy-producing companies, plantation companies, forest companies and carbon-marketing companies), international research organizations, development cooperation agencies and indigenous leaders. ${ }^{19}$ These alliances influence the emphasis given to particular components in the projects.

The outcome of this approach is that private actors and research institutions, which are often international organizations, are creating knowledge and disseminating information about REDD in Latin America. The consequence of this is that these actors position themselves better than public institutions or national research centres and have better resources to influence the international debate. Even Bolivia, with a government strongly sceptical about NGOs, saw the need to include these actors as they have better forest data (e.g. maps) than the government. The way in which they gain this privileged position is by accessing funding from private sources or international development cooperation agencies, coupled with the privileged position in neoliberal environmental governance that they have maintained since the 1990s. To overcome complex issues such as those related to ownership of the land, most 
projects are initiated or planned on private lands. In the following subsection, we focus on measurements to validate REDD projects.

\section{Measures to validate projects}

NGOs, corporations and research institutions are involved in creating standards to certify carbon offsets that can be traded in the voluntary carbon market or in a future REDD carbon market. Organizations involved in pilot projects are also creating standards to demonstrate how they involve local populations in REDD projects.

An illustrative example of this is the Rainforest Standard ${ }^{\mathrm{TM}}$ (RST). This was developed by Columbia University in New York in collaboration with private environmental funds from Bolivia, Peru, Brazil, Ecuador and Colombia. According to its proponents, "this standard integrates carbon-accounting, socio-cultural/socio-economic impacts and biodiversity outcomes into one single REDD standard ${ }^{20 "}$. Projects certified with Royal Forest Society (RFS) can be registered in the Climate Community and Biodiversity Alliance (CCBA) ${ }^{21}$ and in the Verified Carbon Standards (VCS), ${ }^{22}$ to be traded in the voluntary carbon market.

The alliances and associations built among NGOs, the private sector and research institutions contribute to the creation of facts, standards, knowledge and concepts seen as accepted "truths" (cf. Goldman and Turner, 2012). These accepted truths are shaping the direction of REDD in the Amazon basin before governments have managed to put a plan of action into place. For example, in Colombia, where the readiness process is still incipient, BINGOs and local NGOs managed to include the RST as a standard to certify REDD projects by the government in the national REDD strategy. Projects that do not comply with the RST will not be included in the national REDD register of Colombia, and their proponents will not be invited to participate in the debate.

In the following subsection, we focus on alternative channels that different actors are using to engage in REDD. These are particularly relevant in creating a counterbalance to mainstream views and values.

\section{Alternative channels}

REDD networks as described above, in which BINGOs and local NGOs, development cooperation agencies, private actors, government agencies and research institutions participate, are channels where REDD knowledge is being produced and circulated. Such networks have a form of agency in the creation of environmental knowledge that is validated and re-enforced at different levels. Access to REDD networks is not open to all of those who could be interested or affected by REDD policies and 
projects. Participation in REDD networks is conditioned by overriding narratives on deforestation and by the role of monetary incentives in tackling deforestation (see Forsyth, 2003). Activists seeking to influence existing networks may have to decide between working within such dominant rules and establishing alternative and competing networks (Forsyth, 2003; Taylor, 2012). In this way, networks become important resources to advance alternative views and values.

Initially, indigenous peoples were sceptical about REDD and rejected carbon markets because they did not consider them to be offering real solutions to climate change (see the Anchorage declaration adopted by the participants at the indigenous people's global summit on climate change in 2009). ${ }^{23}$ Indigenous organizations in the global South criticize carbon markets and carbon-sequestration projects for their oversimplified portrayal of ecosystems and forests, and for ignoring the socioeconomic, political and institutional implications of carbon sequestration for indigenous peoples.

Indigenous people's organizations in Latin America, and particularly in the Amazon basin countries, have since engaged in existing networks that support REDD, or in alternative networks that are sceptical about REDD and carbon markets. The different paths taken by different indigenous people's organizations are in part explained by previous engagements with other organizations and by their own experiences with REDD. Indigenous people's organizations' choice of position is also influenced by their experiences of negotiating with their governments, and the organization's own visions and priorities.

During the 12th session of the UN Permanent Forum on Indigenous Peoples in 2013, indigenous people's organizations presented two opposing views on REDD, later communicated at COP19 in Warsaw. Some organizations oppose REDD on the grounds that it weakens existing national legal frameworks to protect indigenous people's rights, particularly in regard to territorial and collective land rights, consultation and autonomy, and their opposition to carbon markets and the commodification and fragmentation of nature. Other organizations look at REDD as an opportunity to strengthen the land rights of indigenous peoples and their local management, and to control their territories with the help of direct funding.

The experience of some indigenous people's organizations with so-called "carbon cowboys", particularly in Brazil, Peru, Bolivia and Colombia, has made them extremely aware of some of the risks that REDD projects might entail. Peruvian, Brazilian, Bolivian and Colombian indigenous organizations denounced the fact that 
indigenous leaders signed disadvantageous contracts with private companies. On the other hand, some groups are already developing longterm land-use plans that involve REDD mechanisms defined in their own terms. That is the case of the Suruí in Brazil (Toni, 2011).

The Suruí live in a 247,000 Ha reserve in the state of Rondonia, and $93 \%$ of their land is still preserved (Suruí, 2009). The Suruí population was 5,000 people when they first made contact with non-indigenous Brazilians, but currently only about 1,000 individuals live inside their lands or in the nearby cities. During the 1980s an intense migration of non-indigenous people to the Western Amazonia took place. By the end of that decade, the population had decreased to roughly 250 members.

Despite this drastic reduction of their population, the Suruí started to organize themselves in the 1980s. They created the Metareilá Suruí Association in 1989 to defend and preserve the Suruí's cultural and territorial patrimony.

In 2000, Metareilá started a participatory diagnosis to assess the potential of the Suruís and their territory. Based on this diagnosis, it designed a plan for the use of the territory for coffee cultivation (one of the crops introduced to their land by the invaders), for the management of Brazil nuts, and for the restoration of areas degraded by illegal logging.

With the support of other NGOs (Associação de Defesa Etnoambiental Kanindé, Amazon Conservation Team, Forest Trends, Idesam), the Suruís decided to set aside 13,575.3 Ha of forests for 30 years, which will avoid emissions that average 7,423,806.2 tonnes of $\mathrm{CO}_{2}$. The project was validated in conformance with the Climate, Community and Biodiversity Standards in 2012 (RA-VAL-CCB) and with the Verified Carbon Standard in 2013. Despite the broad alliance that prepared the project, Metareilá has full rights over carbon credits and will be the sole recipient of the financial benefits.

The design of the Suruí Carbon Project included an extensive consultation process, training for community members, development of a baseline for carbon accounting, and analysis of the legal framework regarding indigenous peoples and forest carbon. The Suruís initiated this process in accordance with their own demands; they saw the sale of carbon credits as an opportunity to complement a long-term plan for the development of their community.

\section{Conclusion}

In this chapter we have looked at different strategies employed by Latin American countries and actors in their meeting with the global forest 
and climate initiative, REDD, from resistance to accommodating to assertive strategies. Brazil has been one of the major actors in the initiative after it changed its strategy from resistance to a more offensive approach and managed to align REDD with its own domestic interests. A strong actor such as Brazil has the resources, knowledge and power to shape REDD in its interests, and with the focus on results-based payments, the country is in a privileged position. It has also succeeded in sovereignty issues in international negotiations, such as those related to monitoring, reporting and verification/national forest monitoring systems.

The experiences of the countries that have followed the accommodating strategy show how the history of environmental governance in each country affects the implementation of the REDD initiative. Colombia has, to a large extent, left the initiative in the hands of private actors and local authorities, while Costa Rica has applied a model of "hybrid" governance and a centralized REDD programme. Bolivia has stood out in Latin America as one of the fiercest opponents of carbon markets, something that has affected its possibilities and willingness to take part in the initiative. Bolivia's commitment to the inclusion of civil society demands in environmental governance and the anti-commodification rhetoric has formed its responses to the global initiative. However, there are divergent opinions, especially among the indigenous organizations, about the right path to follow. Indigenous organizations with recognized titles to their land believe that REDD can bring new opportunities. However, although Bolivia's position has been similar to that of Brazil to a large extent, with national sovereignty and opposition to offsets as focal points, Bolivia has instead been seen as the "activist state" that is trying to fragment REDD. It was not until 2013 that Bolivia won support for its alternative mechanism to forest and climate efforts.

These three strategies illustrate how the "black-boxing" of REDD has allowed for the emergence of quite different hybrid models of negotiating environmental governance at the international level.

Our research reveals that there is a constellation of actors shaping the direction of REDD+ in Latin America. That constellation varies from country to country and includes among others, donors, BINGOs and national NGOs, research institutions, and in some cases different levels of government. Through their engagements in networks that promote and advance a narrative in which markets and monetary compensations offer the solution to deforestation, these actors are in a privileged position to participate in the co-production of knowledge and policy, and to advance their agendas. 
For some governments, engaging in REDD - at least at the discursive level - does not conflict with their priorities in other sectors, such as oil exploitation, soy expansion, the expansion of large-scale cattle-ranching, and mining and infrastructure development, which all represent threats to the forests and further deforestation. REDD is seen as an alternative that will allow for the ending of trade-offs between forest conservation, poverty alleviation and economic development. A good example of how this change is unfolding can be found in the partnership between Norway and Brazil. Thanks to REDD, Brazil became the largest receiver of Norwegian development cooperation aid, which is an enormous paradox given that Brazil is one of the fastestgrowing economies in the world. At the same time, but not necessarily as a consequence of such collaboration, Brazil has drastically decreased deforestation in the Amazon.

NGOs have the technical and rhetorical expertise to participate in negotiations in national and international arenas. They also have connections with farmers, indigenous and traditional populations, government officials and bureaucrats. That makes them a privileged set of boundary organizations (Guston, 2001) that can help to break resistance against REDD and to open channels for the implementation of pilot projects. They have been particularly strengthened by REDD due to this role. They are becoming knowledge-providers to governments, donors and local organizations, which has opened the doors for them to policymaking forums. Environmental NGOs are now in a better position to offer business alternatives to corporations and other private actors. Aside from their role as boundary organizations, they are also brokers in REDD implementation and have a direct stake in the negotiations.

The black-boxing of REDD has allowed for the construction of a large and diverse network that supports the initiative. The widespread questioning of the market premises of REDD has led to a broadening of the concept to accommodate disparate interests, ideologies and representations of what forests are and why they should be conserved. That is why countries that have been vocal against REDD, such as Brazil until the mid-2000s, are engaging in REDD preparedness. Accordingly, some groups that initially opposed the mechanism, such as indigenous populations, have pilot projects in their lands as REDD might offer an alternative to strengthen their land rights. However, many indigenous organizations remain critical of carbon markets.

The way in which REDD is going to be financed is still an open question. Although it was born as a market mechanism to trade carbon, political mobilization from different actors has resulted in discussions 
that challenge the market orientation of REDD, and many actors in the Latin American region advocate for a global public fund to finance the initiative. The political opposition of several actors in Latin America has also resulted in a broadening of the focus of REDD to multiple aspects of forests and their related environmental services. In some countries, at the domestic level, it is increasingly assuming the format of a public policy, whereas in the global arena it resembles what Angelsen (2013) has called a "performance-based aid" mechanism. This means that development cooperation funds are used to finance REDD on the condition that countries demonstrate that they achieve certain levels of performance in terms of reduced deforestation.

\section{Notes}

1. http://unfccc.int/resource/docs/2010/cop16/eng/07a01.pdf. See also Angelsen et al. (2009: 3).

2. The final Readiness Plan Idea Note (R-PIN) was never signed by the Bolivian authorities.

3. http://www.lcds.gov.gy.

4. Other donors contributing to UN-REDD are, in order of the size of their contribution, the EU, Denmark, Spain, Japan and Luxembourg. Germany provides $34 \%$ of the total budget of the FCPF. Other donors include Australia, the UK, the USA, Canada, the European Commission, the Nature Conservancy and two private companies: BP Technology Ventures, an alternative energy company with venture investments in projects specific to biofuels, wind and solar energy; and CDC Climat, a company that includes emissions trading and energy investments in its portfolio. The other contributors to the Amazon Fund are Germany and the Brazilian oil company, Petrobras. Sources: http://mptf.undp.org/factsheet/fund/ CCFO0; http://www.forestcarbonpartnership.org/sites/fcp/files/2013/FCPF\% 20Carbon\%20Fund\%20Contributions\%20as\%20of\%20Dec\%2031_2012.pdf; http://www.amazonfund.gov.br/FundoAmazonia/fam/site_en/Esquerdo/ doacoes/; http://www.guyanareddfund.org/index.php?option=com_ content\&view $=$ article\&id=101\&Itemid $=116$.

5. See Readiness Preparation Plans of Colombia, Peru, Ecuador, Guyana and Suriname.

6. In addition to the four BASIC countries (Brazil, South Africa, India and China), representatives from Argentina, Fiji (as chair of the G77 and China), Paraguay, Peru and Venezuela were at the BASIC meeting. http://www. twnside.org.sg/title2/climate/info.service/2013/climate130904.html

7. The Bolivarian Alliance for the Peoples of Our America is a regional organization launched in 2004 and is made up of eight countries: Antigua and Barbuda, Bolivia, Cuba, Dominica, Ecuador, Nicaragua, Saint Vincent and the Grenadines, and Venezuela.

8. Brazilian environmentalists and NGOs (Instituto Socio Ambiental (ISA), Greenpeace, Instituto Centro de Vida (ICV), Instituto de Pesquisa Ambiental 
da Amazonia (IPAM), TNC, CI, Amigos da Terra Amazonia Brasileira (AdT), Instituto do Homen e Medio Ambiente (IMAZON) and WWF-Brazil) launched the Zero Deforestation Campaign. This was based on ideas of strengthening the participation of state governments in forest governance, payments for environmental services, strengthening of protected areas and support for indigenous peoples.

9. According to the former Norwegian oil and energy minister Terje RiisJohansen, the allocation of Norwegian money to the Amazon Fund contributes to opening doors for the Norwegian oil industry in Brazil. Paradoxically, thanks to the commitment to the Amazon Fund, Brazil - one of the largest and fastest-growing economies in the world - has since 2009 become the largest recipient of Norwegian foreign development aid. http://www.dn. no/energi/article1975276.ece « rainforest millions open oil doors ».

10. The Governors Climate and Forest Task Force (GCFT) brings together subnational-level authorities from Brazil, Mexico, Peru, Indonesia, countries in Africa, and the governors' offices of California and Illinois. In this project, California and Illinois will potentially be able to purchase carbon offsets from projects in developing countries, as part of the cap-and-trade programme of these states, which will use a market-based mechanism to reduce greenhouse gases. The GCFT receives funding from the Gordon and Betty Moore Foundation, ClimateWorks, the Climate and Land Use Alliance, the Norwegian Agency for Development Cooperation (Norad), and the David and Lucile Packard Foundation. Collaborating partners include NGOs from Brazil (Institute for the Conservation and Sustainable Development of Amazonas -DESAM and Amazon Environmental Research Institute IPAM), Indonesia (Kemitraan), Mexico (ProNatura), a transnational private company (ClimateFocus), and the US-based private research organizations the Carnegie Institution for Science and the Woods Hole Research Center.

11. WWF, CI, TNC.

12. See the report of the due diligence mission of the World Bank to Colombia, 15-27 January and 22-23 March 2012. http://documents.worldbank.org/ curated/en/2012/04/16508452/colombia-fcpf-redd-readiness-project-aidememoire-april-18th-25th-2012

13. In addition to the FCPF, other sources of funding include GIZ through the REDD-CCAD-GIZ programme, which has financed different activities in Costa Rica with special emphasis on forest reference level; the Norwegian development agency (Norad); and USAID.

14. Later it turned out that the Bolivian officials were against the total rejection of REDD.

15. The UN-REDD team respected the Bolivian position at the time and said they would not intervene in the funding for the Bolivian programme.

16. In total, US\$1.4 million. Source: Diego Pacheco.

17. The REDD desk is funded by the Gordon and Betty Moore Foundation, the Climate and Land Use Alliance, the Department of Climate Change and Energy Efficiency of the Australian Government, GIZ and USAID.

18. http://reddplusdatabase.org.

19. Interview FAN; interviews Colombia.

20. http://cees.columbia.edu/the-rainforest-standard and interview FAN. 
21. The CCBA is a partnership between research institutions (CATIE, CIFOR, and ICRAF), corporations (the Blue Moon Fund, The Kraft Fund, BP, Hyundai, Intel, SC Johnson, Sustainable Forestry Management, and Weyerhaeuser) and NGOs (CARE, CI, TNC, the Rainforest Alliance and WCS).

22. The VCS was established in 2005 by the Climate Group, the International Trading Association and the World Business Council for Sustainable Development. It is one of the world's most widely used carbon-accounting standards. Projects across the world have issued more than 100 million carbon credits using VCS standards. VCS headquarters are in Washington, DC, with offices in China and South America.

23. http://www.unutki.org/downloads/File/Events/2009-04_Climate_Change_ Summit/Anchorage_Declaration.pdf

\section{References}

Agrawal, A., Nepstad, D. and Chhatre, A. (2011) "Reducing Emissions from Deforestation and Forest Degradation", Annual Review of Environment and Resources 36: 373-396.

Alesina, A., Carrasquilla, A. and Echavarria, J.J. (2005) "Decentralization in Colombia" in A. Alesina (ed.), Institutional Reforms. The Case of Colombia (Cambridge, MA: MIT Press).

Alvarez, M.D. (2003) "Forests in the Time of Violence", Journal of Sustainable Forestry 16(3-4): 47-68.

Angelsen, A. (2013) REDD+ as Performance-Based Aid: General Lessons and Bilateral Agreements of Norway. Working Paper (s.d.:WIDER).

Angelsen, A., Brown, S., Loisel, C., Peskett, L., Streck, C. and Zarin, D. (2009) Reducing Emissions from Deforestation and Forest Degradation (REDD): An Options Assessment Report. Prepared for the Government of Norway (Washington: Meridian Institute).

Angelsen, A. and McNeill, D. (2012) "The Evolution of REDD+", in A. Angelsen, M. Brockhaus, W.D. Sunderlin and L.V. Verchot (eds), Analysing REDD+ Challenges and Choices (Bogor, Indonesia: CIFOR).

Barcena, A., Prado, A., Samaniego, J. and Malchik, S. (2010) "Climate Change: A Regional Perspective", Unity Summit of Latin America and the Caribbean Riviera Maya. ECLAC; IDB. Riviera Maya, Mexico.

Bernstein, S. (2004) "Legitimacy in Global Environmental Governance", Journal of International Law and International Relations 1(1-2): 139-166.

Blom, B., Sunderland, T. and Murdiyarso, D. (2010) "Getting REDD to Work Locally: Lessons Learned from Integrated Conservation and Development Projects", Environmental Science and Policy 13(2): 164-172.

Boyd, E., Gutierrez, M. and Chang, M. (2007) "Small-Scale Forest Carbon Projects: Adapting CDM to Low-Income Communities", Global Environmental Change 17(2): 250-259.

Bull, B. and Aguilar-Støen, M.C. (eds) (2015) Environmental Politics in Latin America: Elite Dynamics, the Left Tide and Sustainable Development (London: Routledge Studies in Sustainable Development).

Fairhead, J. and Leach, M. (2003) Science Society and Power: Environmental Knowledge and Policy in West Africa and the Caribbean (Cambridge: Cambridge University Press). 
Forsyth, T. (2003) Critical Political Ecology. The Politics of Environmental Science (New York: Routledge).

Goldman, M., Nadasdy, P. and Turner, M.D. (2011) Knowing Nature: Conversations at the Intersection of Political Ecology and Science Studies (Chicago: University of Chicago Press).

Guston, D.H. (2001) "Boundary Organizations in Environmental Policy and Science: An Introduction", Science, Technology, and Human Values 26(4): 399-408.

Hall, A. (2008) "Paying for Environmental Services: The Case of Brazilian Amazonia", Journal of International Development 20(7): 965-981.

Hall, A. (2011) "GETTING REDD-Y Conservation and Climate Change in Latin America", Latin American Research Review 46: 184-210.

Karkkainen, B.C. (2004) "Post-Sovereign Environmental Governance", Global Environmental Politics 4(1): 72-96.

Latour, B. (1987) Science in Action: How to Follow Scientists and Engineers Through Society (Cambridge: Harvard University Press).

Li, T.M. (2007) The Will to Improve. Governmentality, Development and the Practice of Politics (Durham: Duke University Press).

Meyer, P.J. (2010) Brazil-US Relations (Washington, DC: Library of Congress Congressional Research Service).

Nepstad, D., Soares-Filho, B.S., Merry, F., Lima, A., Moutinho, P., Carter, J., Bowman, M., Cattaneo, A., Rodrigues, H., Schwartzman, S., McGrath, D.G., Stickler, C.M., Lubowski, R., Piris-Cabezas, P., Rivero, S., Alencar, A., Almeida, O. and Stella, O. (2009) The end of deforestation in the Brazilian Amazon. Science 326:1350-1351.

Pacheco, P., Aguilar-Støen, M., Börner, J., Etter, A., Putzel, L. and Diaz, M.d.C.V. (2010) "Landscape Transformation in Tropical Latin America: Assessing Trends and Policy Implications for REDD+", Forests 2(1): 1-29.

Pagiola, S. (2008) "Payments for Environmental Services in Costa Rica", Ecological Economics 65(4): 712-724.

Peet, R., Robbins, P. and Watts, M. (2011) "Global Nature", in R. Peet; P. Robbins and M. Watts (eds), Global Political Ecology (Abingdon UK: Routledge), 1-48.

Russo, R.O. and Candela, G. (2006) "Payment for Environmental Services in Costa Rica: Evaluating Impact and Possibilities", Tierra Tropical 2(1): 1-13.

Sanchez-Azofeifa, G., Harriss, R.C. and Skole, D.L. (2001) "Deforestation in Costa Rica: A Quantitative Analysis Using Remote Sensing Imagery", Biotropica 33(3): 378-384.

Santilli, M., Moutinho, P., Schwartzman, S., Nepstad, D., Curran, L. and Nobre, C. (2005) "Tropical Deforestation and the Kyoto Protocol", Climatic Change 71(3): 267-276.

Scott, J. (1998) Seeing Like a State: How Certain Schemes to Improve the Human Condition have Failed (London/New Haven: Yale University Press).

Suruí, A.N. (2009) "Projeto Carbono Suruí", Presented at the Curso para Lideranças Comunitárias, Pagamentos por Serviços Ambientais. http://www.katoombagroup. org/documents/events/event33/Apresentacoes/EstudodeCaso_Almir_Surui_1. pdf, date accessed 13 September 2014.

Taylor, P.J. (2012) "Agency, Structuredness, and the Production of Knowledge within Intersecting Processes", in D. Goldman; P. Nadasdy and M. Turner (eds), Knowing Nature. Conversations at the Intersection of Political Ecology and Science Studies (Chicago: The University of Chicago Press), 81-98. 
Toni, F. (2011) "Decentralization and REDD+ in Brazil", Forests 2(1): 66-85.

Wunder, S. (2005) Payments for Environmental Services: Some Nuts and Bolts, Occasional Paper No. 42 (Jakarta, Indonesia: CIFOR).

(c) (i) Except where otherwise noted, this work is licensed under a a copy of this license, visit http://creativecommons.org/licenses/by/3.0/ 